\title{
Internal Lateral Ligament of the Ankle
}

National Cancer Institute

\section{Source}

National Cancer Institute. Internal Lateral Ligament of the Ankle. NCI Thesaurus. Code C32850.

A flat, triangular fibrous tissue connected to the inner malleolus, navicular bone and ligament, os calcis and astragalus. 